Vol. 18 (2009): 268-282.

\title{
Review article Assessment of cleanness of environmental surfaces in cattle barns and piggeries
}

\author{
*Hanna-Riitta Kymäläinen, Risto Kuisma, Jenni Määttä and Anna-Maija Sjöberg \\ Department of Agrotechnology, PO Box 28 (Koetilantie 3), FI-00014 University of Helsinki, Finland, \\ *e-mail: hanna-riitta.kymalainen@helsinki.fi
}

\begin{abstract}
Hygienic issues are important in environmental surfaces of animal houses because of food quality and animal welfare. The aim of this study was to review methods in cleanability research of cattle barns and piggeries. Surface materials, animal welfare and hygiene are also discussed. Concerning different detection methods of cleanness, visual methods have dominated in field studies, but some successful attempts to use optical methods are also presented. A wider selection of different kinds of instrumental, microbiological and visual methods and their combinations have been used in laboratory studies. Radiochemical methods have been demonstrated to be suitable as quantitative laboratory methods. In the case of material studies, laboratory experiments are important prior to field experiments in order to screen potential materials, whereas the field studies provide practical information about the behaviour of the surface materials. The importance of cleanness of environmental surfaces in cattle barns and piggeries is also discussed in the context of material development.
\end{abstract}

Key-words: hygiene, cleanability, animal house, cattle barn, piggery, cow, surface, detection, measurement, method

\section{Introduction}

Hygienic issues are important in environmental surfaces of animal houses because of food quality, animal welfare and even safety of the personnel. The cleanness of surfaces in cattle barns and piggeries is affected by many factors e.g. size, lay-out and surface materials of pens and other sections (Aarnink and Wagemans 1997, de Belie et al. 2000b, Barker et al. 2007). Factors affecting soiling, namely the 
Vol. 18 (2009): 268-282.

type of feed and feeding methods have an effect on the quality of manure (Mathiasson et al. 1991, de Belie et al. 2000b, Calleja Carrete 2005, Aarnink and Verstegen 2007). Furthermore, environmental conditions such as indoor temperature and moisture content as well as cleaning methods and frequency affect cleanness of the surfaces. Assessment of cleanness of environmental surfaces in animal houses has not very often been studied. The main aim of this survey is to review detection methods of cleanability, because farm hygienic measures are important criteria for the safety and quality of both meat (Berends et al. 1996, Maw et al. 2001, Wong Lo Fo et al. 2002, Andersen et al. 2005) and milk (de Koning et al. 2003, Hanus et al. 2004, Skrzypek 2006, Trevisi et al. 2006). Studies including detection and measurements of cleanness in cattle barns and piggeries are examined, and the importance of hygiene and the methodological knowledge obtained in these studies are discussed.

Many demands are applied to surfaces in animal houses. Since cleanability and hygiene are not the only important material properties, material development and selection is based on several criteria. These include thermal comfort, softness, friction, abrasiveness and contact pressure between animal and floor (Nilsson 2005, Puumala et al. 2006, Mahlberg et al. 2008). However, in this review surface materials and indoor air contaminants in cattle barns and piggeries as well as animal welfare are introduced first as background information, since they are closely connected to the methodology used in hygienic monitoring and cleanability studies of agricultural surfaces.

\section{Surface materials}

Both chemical substances and mechanical impact on environmental surfaces cause corrosion and wear, which leads to the need to examine not only new but also worn surfaces. For example in the study by Määttä et al. (2009), mechanical wear decreased the cleanability of all surface materials, namely concrete and its treatments and coatings, as well as that of joints. In material studies focusing on cleanability, wearing must therefore be taken into consideration. Concrete is one of the most frequently used building materials in agricultural constructions (de Belie 1997). Although concrete is often very suitable for agricultural environments, it is affected by many environmental hazards, e.g. wear caused by animals and vehicles and chemical load caused by feeds, milk and manure (standard ACI 515.1R-79 1985, Mathiasson et al. 1991, de Belie 1997, de Belie et al. 1996, 2000a, 2000b, Bertron et al. 2005, Nilsson 2005, Abdelmseeh et al. 2008, Sánchez et al. 2008).

The wearing of concrete has provided motivation for material studies focusing on finding alternatives and improvements for concrete surfaces (Barbucci et al. 1997, de Belie et al. 2000a, Naik et al. 2002, Almusallam et al. 2003, Calleja Carrete 2005, Yazıcı and İnan 2006, Moon et al. 2007, de Muynck et al. 2008, Kuisma et al. 2008b, Kymäläinen et al. 2008, Määttä et al. 2008, 2009). Alternative surfaces include coatings and thin surface treatments. Coatings can be used to limit water penetration into concrete, which is a porous material. For example epoxycoating has been shown to improve cleanability, and in general decreasing water-permeability of concrete has been shown to improve its microbiological hygiene (Pelletier et al. 2002). Coatings also improves the cleanability of concrete (Kymäläinen et al. 2008, Kuisma et al. 2008b, Määttä et al. 2008). In some studies other materials than concrete were included, for example wood as a material of cattle barns has been reviewed by de Belie et al. (2000b) and metal by de Belie et al. (2000c). In some studies the use of bedding materials (Ruunaniemi et al. 2005) and straw (Tuyttens 2005) has been the focus of attention rather than the structural, permanently installed surface material itself.

\section{Animal welfare and hygiene}

The choice of surface materials in agricultural environments affects animal welfare and the management of hygiene (Määttä et al. 2008). Construction of barns and surface materials should promote the well-being of animals by allowing the 
Kymäläinen, H.-R. et al. Assessment of cleanness of surfaces in animal houses

species-characteristic behaviour and convenience of the animals and preventing injuries and diseases (Baxter 1984, Hoy et al. 1999, Vokey et al. 2001, Tuyttens 2005). One of the most important aspects of materials is slipperiness of the floorings (Määttä et al. 2008). Rushen and de Passillé (2006) stated that it is important to keep walking areas as clean and dry as possible to ensure good locomotion, rather than to rely on nonslip floorings. However, floor material and its roughness is connected to the risk of claw lesions due to local surface overload (Wells et al. 1999, Vokey et al. 2001, de Belie and Rombaut 2003). A floor surface which is too rough causes rapid wear of animal hooves and grazes on other parts of the body, and floors with an initially ideal surface may become too rough or slippery because of degradation (de Belie 1997). On the other hand, despite the fact that soft flooring provides good locomotion comfort for dairy cows, some incidents and diseases are more common on soft floorings than on concrete (Kremer et al. 2007), and a moderate abrasion by the flooring is required to prevent claw overgrowth (Kremer et al. 2007, Telezhenko 2007). Thus a single factor or parameter, such as wearing and slipperiness used here as examples connected to cleanness, is complicated in practice. Prioritizing and compromising is needed in material research. Material selection and durability are also closely linked with economical considerations. The importance of this subject is emphasized in large animal buildings, which are nowadays common in many countries.

In addition to the direct consequences of floor roughness on the health of animals, rough floor surfaces may make cleaning difficult, thus indirectly promoting the spread of diseases (de Belie 1997, de Belie et al. 2000b). Microbes of manure can accumulate on the barn floor and infect other animals or humans (Pell 1997). For example Salmonella can enter the food chain at any point throughout its length, e.g. from livestock feed, via the on-farm production site, at the slaughterhouse or packing plant, and in manufacturing, processing, retailing, catering and preparation of food (Wong Lo Fo et al. 2002). In a study by Pell (1997), the most important microbes in manure were reviewed in detail.
Many of the hygienic problems concerning animal welfare are also connected to comfort of the personnel working in the barn. For example according to a study by Xiao et al. (1994), diseases in for both humans and animals caused by Cryptosporidium and Giardia are enhanced by unhygienic practices and insufficient removal of waste from pig pens. A specific point focused on in several studies is the indoor air quality in animal houses. This is a wide issue affecting both animal welfare and the working environment of the farmer. Although it is outside the scope of this study, indoor air is briefly mentioned here because the soils and cleanness of the surfaces in animal houses are closely associated with particle and chemical emissions in the air (Sun et al. 2008). For example dustiness caused e.g. by floorings and poor hygiene has been shown to be associated with dust exposures in pig farmers (Preller et al. 1995). Indoor air contaminants in piggeries, their causes and consequences were discussed in the review by Cole et al. (2000). Dust and means for preventing it in indoor air in piggeries were presented by Pedersen et al. (2000). Structural improvements e.g. in the slope of the floor to reduce emissions in the indoor air of cattle barns were examined by Swierstra et al. (1995) and Braam et al. (1997a, b), and cleaning of the exhaust air from animal buildings by Ndegwa et al. (2008).

\section{Assessment of cleanness in animal houses}

According to the presented literature it is evident that hygienic demands in animal houses are acute and important. Assessment of cleanness in animal houses has not previously been reviewed as a whole. Environments of animal houses present an interesting combination of different rooms and levels of hygiene close to each other. An example of a section with relatively high hygienic needs are milking stations in cattle barns. Physically close to these in the cattle barns are sections often covered with a macroscopic level of soil, as manure on the floors. 
Vol. 18 (2009): 268-282.

\section{Methods in cleanability research}

Studies concerning the cleanability of materials in cattle barns and piggeries are presented in Tables 1-3. Some of these studies were discussed by Määttä (2007) and Kuisma et al. (2008b). The aims and motivation of these studies have often been to compare surface materials, or to examine structural solutions of the animal houses or the welfare of animals (Tables 1-3). The research methods for cleanability have been divided into three categories: visual, microbiological and instrumental, the last of which includes chemical and physical methods. Only a few of the studies presented in the tables focus purely on cleanability issues, but details relating to cleanability were selected from the studies. The tables may thus not give the whole picture of a specific study but rather the aim is here to present a spectrum of methods of cleanability investigation in different kinds of studies in cattle barns and piggeries. Since the methodological background for laboratory and field studies is often different, an indication of this feature is included in the tables. Furthermore, surface materials are mentioned because they are a major factor affecting soiling, cleaning and selection of detection methods. Soil is of interest in all cleanability studies because it affects directly the selection of the detection method. In addition to these considerations, other possible criteria for determining dirty and clean areas are also mentioned in the tables.

The most frequently used detection methods are visual and qualitative methods (Table 1). These methods are the most typical in various kinds of field studies but have also been used in laboratory studies, particularly in earlier works. In addition to concrete, several other surface materials were examined in these studies. In most cases the visual methods were used without a specified scale, or only an approximate qualitative division into soiled and cleaned surfaces was used without strictly presented criteria (Table 1). More advanced visual assessment methods use the percentages of soiled and clean surfaces (Ni et al. 1999, Svensson et al. 2006). Some researchers, e.g. Gaworski et al. (2003), divided the environmental area of interest into squares and deduced the soiled area from summing evaluations of the squares, which might lead to a somewhat better accuracy of the measurement than pure qualitative assessment. In the studies by Stefanowska et al. (2001) and Ye et al. (2007) a visual assessment method was used, but the results were processed using an image analysis program.

Studies using microbiological methods (Table 2 ) are less numerous than those using visual methods (Table 1). In the case of microbiological methods, concrete was included in many of the studies but a variety of other surface materials were also examined. In a study by Larsson (2000), the main assessment method was visual, but a protein test and microbiological contact slides were also tested for evaluating the effect of cleaning in pig pens. Lorentzon (2005) studied microbiological methods for examining the floor bulk soil, whereas in a study by Pelletier et al. (2002) swabbing or plate count agar methods were used. In most studies no strict criteria for cleanness were presented, with the exception of the study by Böhm (1998), who stated that $10^{3} \mathrm{cfu} / \mathrm{cm}^{2}$ of total bacteria was equivalent to disinfected.

Instrumental detection methods are presented in Table 3. Radiochemical methods have earlier been used for cleanability studies of flooring materials in public buildings (Ohlson and Wäänänen 1971, Jokelainen and Uusi-Rauva 1976, Engström and Bäckström 1987, Pesonen-Leinonen et al. 2006, Määttä et al. 2007), but were recently also adopted for agricultural surfaces. These methods provide quantitative information on the amount of soil both on the surface and soaked into the material and thus differ from other methods included in Tables $1-3$. This capability is especially important when porous materials such as concrete are examined. The radiochemical methods developed have thus been successfully used for comparative materials studies including concrete, joints and also plastic surfaces (Kymäläinen et al. 2008, Määttä et al. 2008, 2009).

Detection methods using visual sensors or colorimetry have been used in both laboratory and field studies (Table 3). The detection methods developed, based on visual sensor systems, have been 
Kymäläinen, H.-R. et al. Assessment of cleanness of surfaces in animal houses

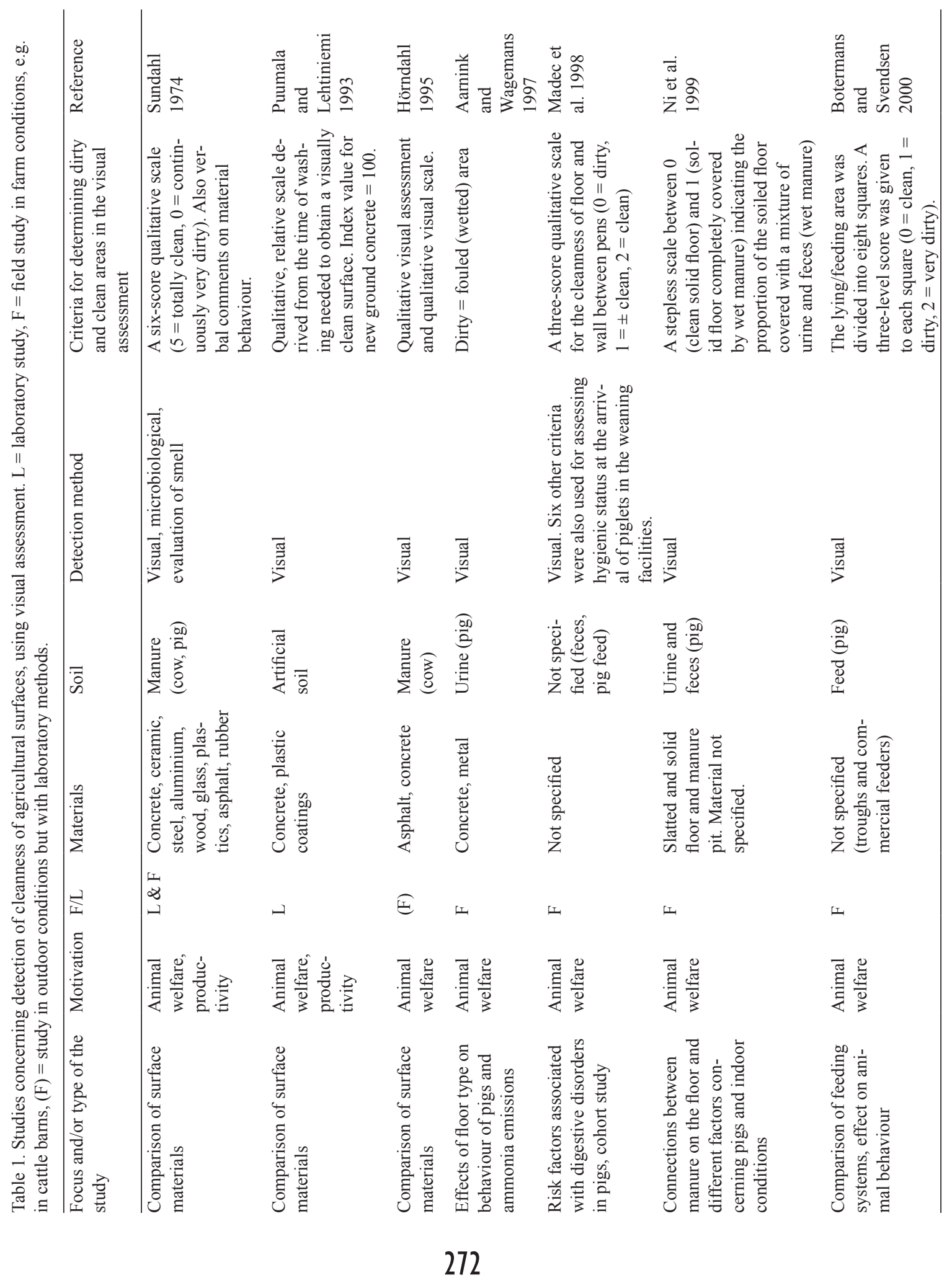


Vol. 18 (2009): 268-282.

\begin{tabular}{|c|c|c|c|c|c|c|}
\hline 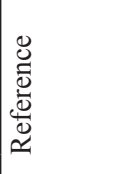 & 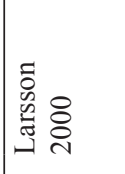 & 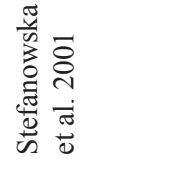 & 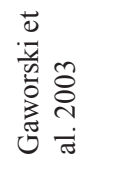 & 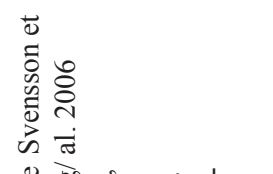 & 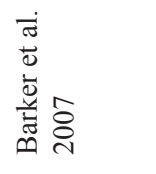 & 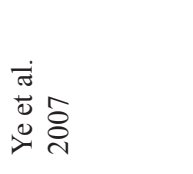 \\
\hline 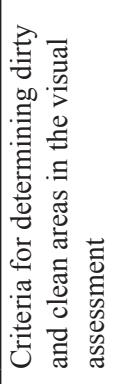 & 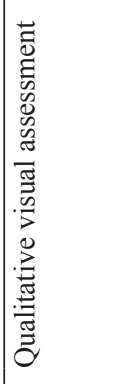 & 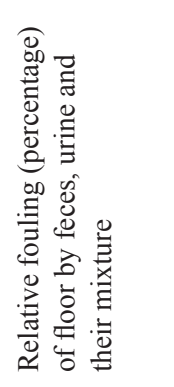 & 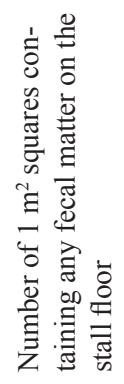 & 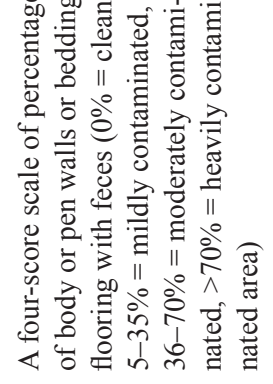 & 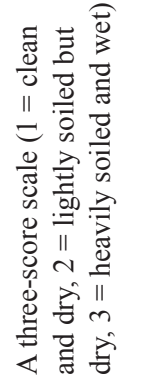 & 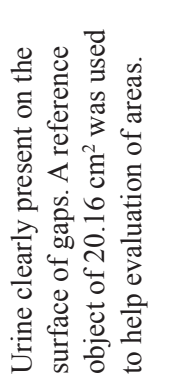 \\
\hline 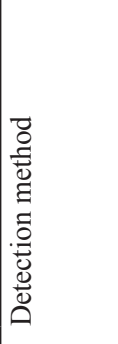 & 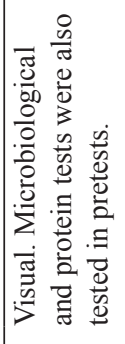 & 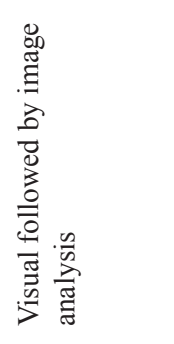 & 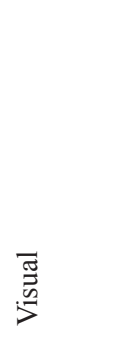 & $\stackrel{5}{5}_{5}^{\overline{5}}$ & 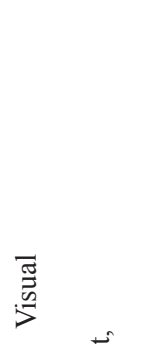 & 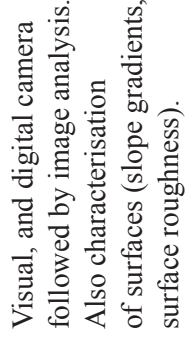 \\
\hline $\begin{array}{l}\overline{\bar{\sigma}} \\
\mathscr{n}\end{array}$ & 言 & 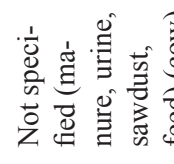 & 旁全 & 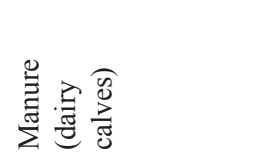 & 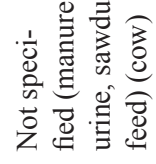 & 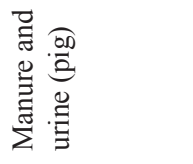 \\
\hline 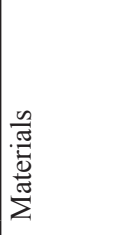 & $\begin{array}{l}\text { D } \\
0 \\
\vdots \\
3 \\
0 \\
0 \\
0 \\
0 \\
0 \\
0\end{array}$ & 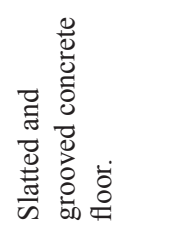 & 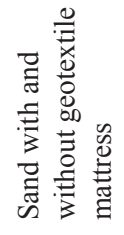 & 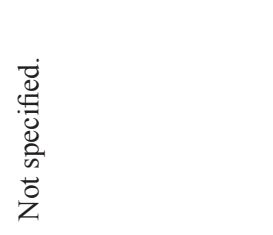 & 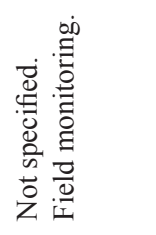 & 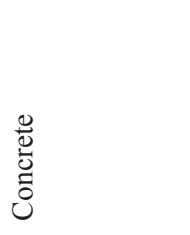 \\
\hline$\stackrel{\vec{I}}{\vec{I}}$ & IL & L & L & $\omega$ & 工 & 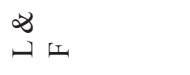 \\
\hline . & 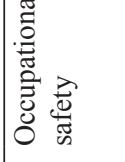 & 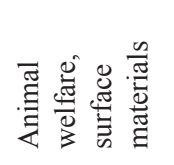 & 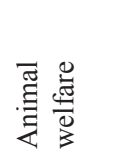 & 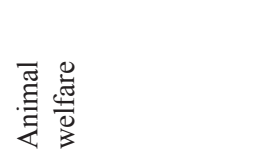 & 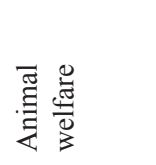 & 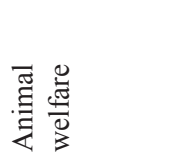 \\
\hline 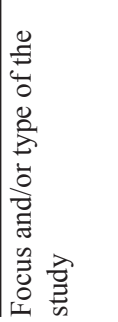 & 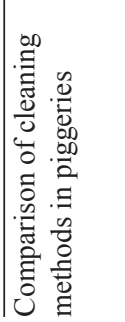 & 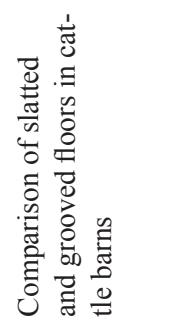 & 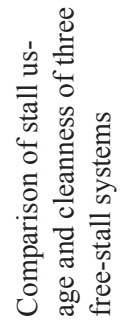 & 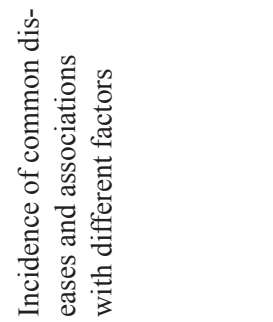 & 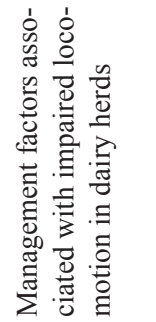 & 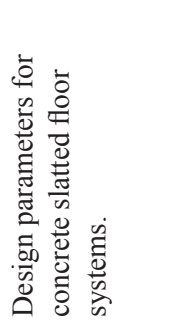 \\
\hline
\end{tabular}


Kymäläinen, H.-R. et al. Assessment of cleanness of surfaces in animal houses

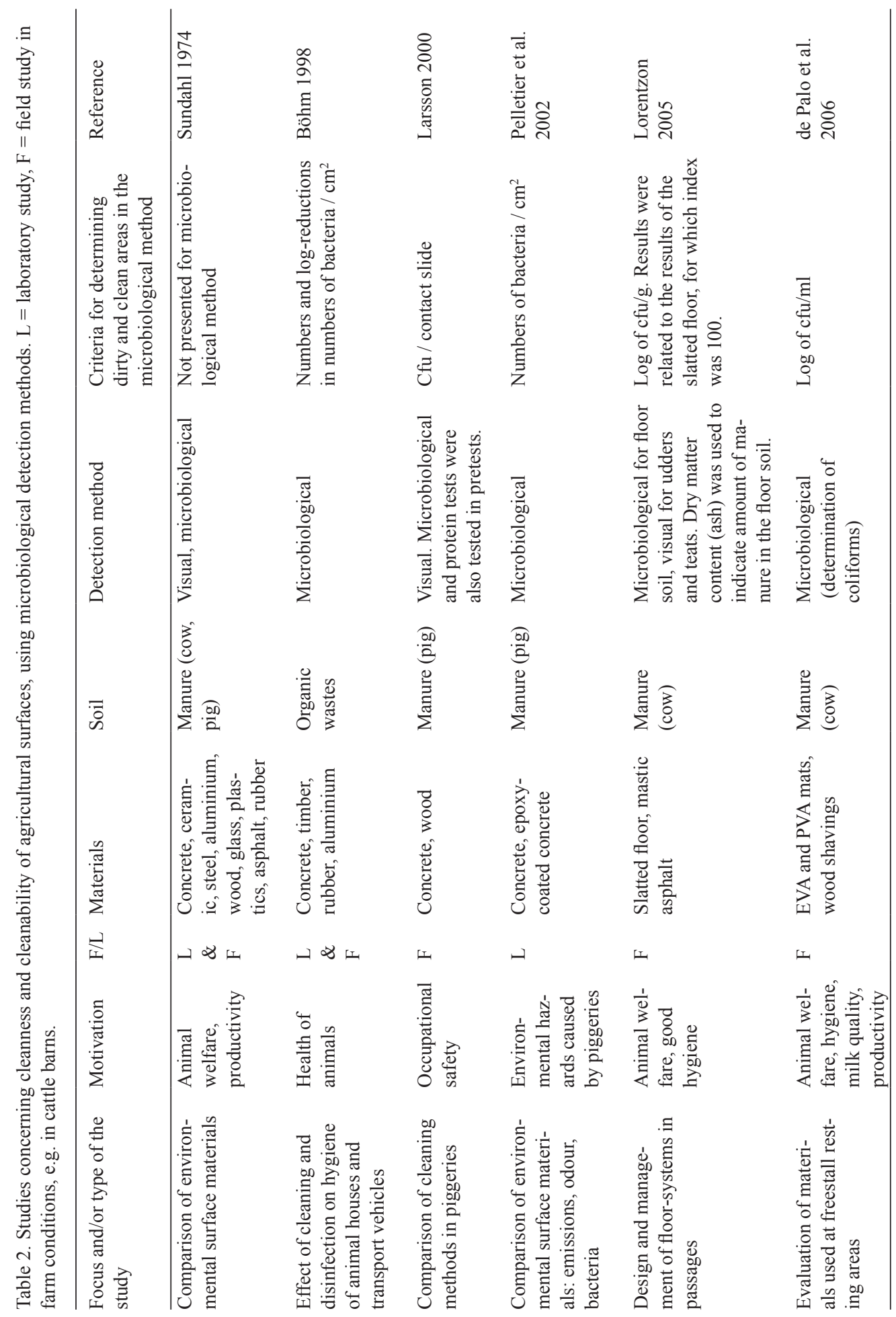


Vol. 18 (2009): 268-282.

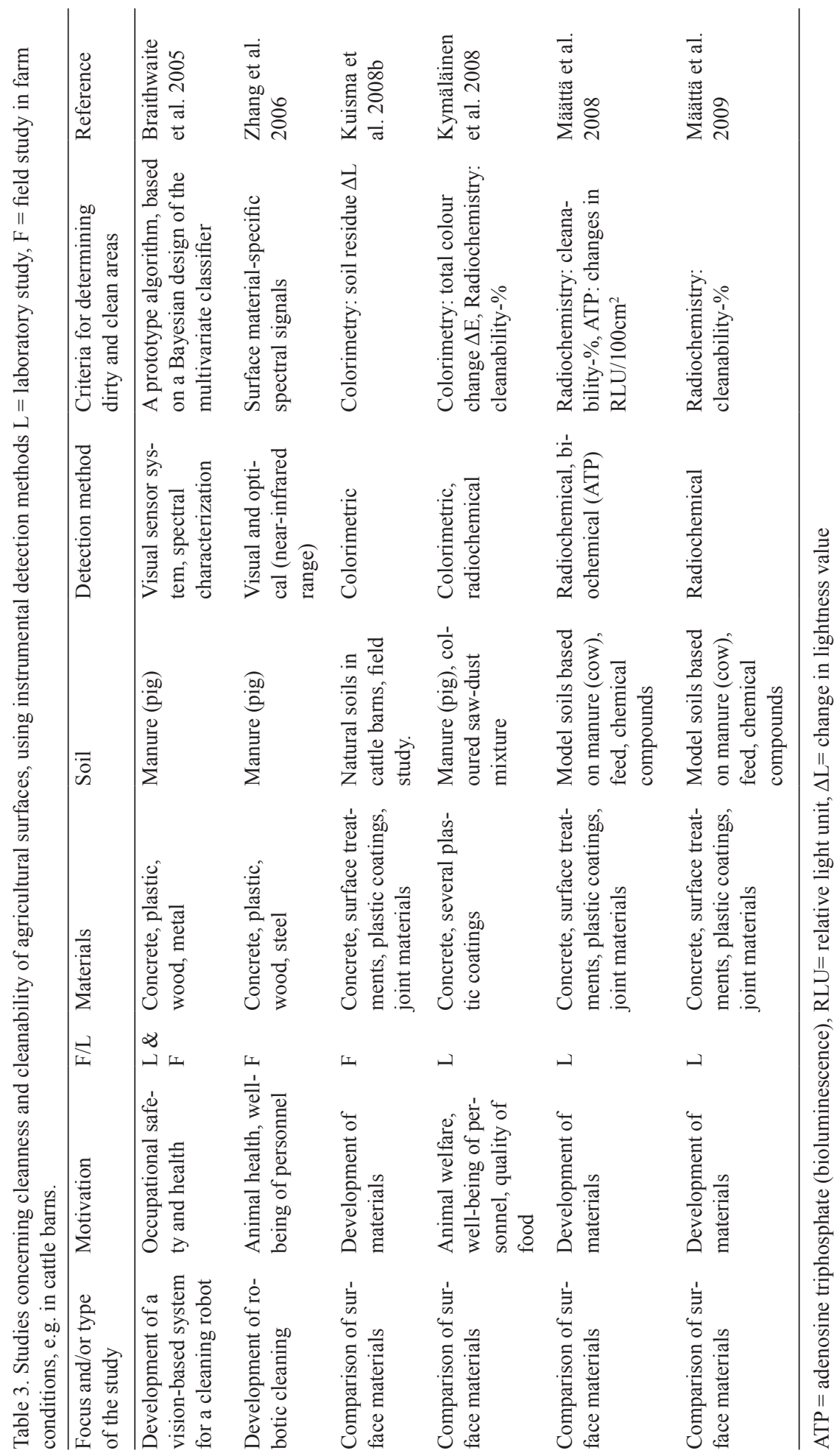




\section{Kymäläinen, H.-R. et al. Assessment of cleanness of surfaces in animal houses}

shown to be able to locate dirty areas in field conditions (Braithwaite et al. 2005, Zhang et al. 2006).

Some of the studies using visual assessment (Table 1) and instrumental methods (Table 3) also included characterization of surfaces. Roughness (Ye et al. 2007, Kymäläinen et al. 2008, Määttä et al. 2008, 2009, Kuisma et al. 2008b) as well as have been used for surface characterization, as well as variations in slope gradients (Ye et al. 2007).

Studies focusing on dust on surfaces in animal houses are rare. Miller and Woodbury (2003) developed methods for examining the dust potential of feedlot soils, the background motivation being human and animal welfare. In their study, samples of mixtures of manure and soil were gathered from feedlot pens. Moisture and organic matter contents of the mixture, as well as mass and volume of dust were measured. Dust (Preller et al. 1995, Wathes et al. 1998, Pedersen et al. 2000, Almuhanna 2007) and also other emissions (Harry 1978, Wathes et al. 1998, Cole et al. 2000) have been measured from the air. In a study by Preller et al. (1995) the focus was on indoor air, particularly on factors affecting personal dust and endotoxin exposure levels of pig farmers. However, although dust was detected from air and endotoxins were measured from the air samples, surface dustiness was also evaluated visually. As a result, aspects of hygiene (e.g. dust and dry manure in compartments) and feeding were observed to be the major characteristics associated with dust exposure.

In some studies focusing on hygiene issues in animal houses, hygiene aspects of surfaces or structures have been evaluated indirectly. A typical indirect method is to assess the cleanness of a part of the building, e.g. the animal house, by assessing the surface of the animal body. As an example in a study by Scott et al. (2007) pig skin was assessed visually, and other criteria for animal welfare were also used. The aim of their study was to evaluate liquid feeding from the point of view of animal welfare, including hygiene. Interestingly, cleanness was defined as "the percentage of body surface of pigs which was clean as opposed to soiled". Another example of indirect monitoring was presented in the study by Phillips and Phillips (1999), in which the behaviour of animals indicated cleanness of feeding equipment. In their study the experimental float bowl feeding equipment easily became soiled with urine, feces and feed, and piglets chose not to drink from an unclean vessel. A third example of indirect measurements is used in many studies examining the effects of hygiene practices and other factors affecting quality of food products. The quality of a typical food product, milk, is affected by several hygiene-related parameters e.g. by unsanitary conditions associated with unclean udders before milking, poor teat and teat-end sanitation, cleaning and sanitation of milking equipment and cooling of milk. In a study by Hultgren and Bergsten (2001), the effects of a manure-draining rubber-slat system on hygiene and foot health in tied dairy cows were evaluated. According to the visual three-level scoring of cleanness and health of cows, animals kept in standing areas with a rubber-slatted floor were cleaner than those housed on a fully solid rubber mat. Mottram (1997) presented different methods used to assess cleanness of udder and teats of milking cows. In a study by Jayarao et al. (2004), categorized somatic cell and bacterial counts in bulk tank milk were observed to serve as possible indicators and facilitate monitoring of herd udder and milk quality. In a study by Farzan et al. (2006), possible association of liquid-feeding and dry-feeding with Salmonella was examined using detection of Salmonella in feces. In a study by Siekkinen et al. (2006), the research method was based on a questionnaire focusing on several factors related to hygiene, and some answers probably included visual assessment.

\section{Hygiene in piggeries and cattle barns}

When evaluating detecting methods of cleanness the importance of hygiene should be discussed as a background issue. Hygienic practices consist of several different factors. In the study by Siekkinen et al. (2006) a list of factors was used in hygiene evaluation for finishing pigs at the pre-harvest level, including general production management, animal density, the outdoor area for pigs, pests and pet animals, general hygiene in the piggery, pen hygiene, 
Vol. 18 (2009): 268-282.

feed production hygiene and feeding hygiene. This study also referred to other studies providing results concerning means for improvement. In a study by Madec et al. (1998), hygiene at the reception of the piglets (cleanness, temperature) was an important factor leading to risky or secure profiles concerning digestive disorders in pigs, but hygiene at the management and husbandry level (air quality, group size and stocking procedure) was also important. Although good hygiene and management are important, they are not always sufficient to reduce microbes, as in the case of Salmonella shedding in the study by Farzan et al. (2006). Whole feeding systems have been shown to be associated with prevalence of harmful microbes (Farzan et al. 2006, Phillips and Phillips 1999). From another point of view, Farzan et al. (2006) observed in Canada that although liquid feeding systems may be difficult to clean, modern liquid-feeding farms are possibly more likely to carry out improved practices of cleaning and rodent control than farms using traditional dry-feeding. As an example of structural factors, the type of slatted floor was shown to influence the fouling of the solid floor in piggeries (Aarnink and Wagemans 1997). Hautekiet et al. (2008) presented a sanitary risk index (SRI) covering many important details in pig farms. Cleaning and hygiene has been included at several control points in an HACCP (Hazard Analysis Critical Control Point) system developed for piggeries (von Borell et al. 2001),

In milk production, coliforms from manure or bedding, spore-forming bacteria from silage, and potentially zoonotic bacteria may place consumers at risk (Slaghuis 1996, Sumner 1996). Hygiene is a major aspect throughout the milking process (Ipema 1997). The increase in total bacterial count in raw milk often originates partly from contamination of milk from the teat surface and partly from lack of cleaning of the automatic milking equipment or cooling of the milk, when the increase in spores of anaerobes is used as an indicator (Galton et al. 1982, Rasmussen et al. 2002). Mastitic milk is the third factor affecting microbiological quality of milk (Galton et al. 1982). Since cleanness of the teats before cleaning has a significant effect on the effectiveness of teat cleaning (Hovinen et al. 2005), hygienic measures aiming to keep the cattle clean are essential. Cleanness of the udders and teats depends to a large extent on the accommodation, which means an adequate design and layout of the resting and feeding areas, and the use of scrapers. However, Barker et al. (2007) reported that despite the fact that automatic scrapers can improve hygiene in free-stall barns because of frequent scraping, they can make cows dirtier because of the wave of slurry that coats the claws and possibly the lower legs of cattle. According to a study by Hovinen et al. (2005), hygienic maintenance of the milking stable and automatic milking machine, as well as full utilization of the adjustability of the brush- or cup-cleaning mechanism to suit herd or cow characteristics, are also essential in preventing teats from becoming soiled in the milking stall. Cubicle cleaning twice per day, shearing of udders and cutting of tail brushes have been considered to be important for teat cleanness (Knappstein et al. 2004). These operations were carried out in the majority of the farms examined and were thus generally accepted hygiene measures to keep cows clean. Knappstein et al. (2004) also reported that if the management of animal health is good, more attention is also paid to cow comfort and cleanness.

In actual practice, cleanness may also be connected to technical aspects in cattle barns. For example in some automatic feeding equipment soiling of electricity cables may cause operation breakdown (Gjødesen 2007). As another example the use of manure scrapers improves comfort and indoor air quality on grooved and slatted floors. However, in order to prevent stumbling incidents, functioning of the manure scraper needs to be optimized (Stefanowska et al. 2001).

\section{Laboratory and field studies}

In field studies, soil is a varying mixture consisting of manure, urea, bedding material such as sawdust, outdoor soil such as mud, dust and feed. In practical conditions soil is deposited on surfaces in different ways, e.g. by dropping, splashing or via direct surface contact (Mottram 1997), which affects 


\section{Kymäläinen, H.-R. et al. Assessment of cleanness of surfaces in animal houses}

the severity of soiling and adherence of soil on surfaces. The natural soil on surfaces is often an undefined mixture. However, in some laboratory studies the composition of natural soil, manure, has been determined (Määttä et al. 2008). In laboratory studies soils vary from pure chemical components to artificial mixtures of model soils and natural soils, such as manure and feed.

The methodology for cleanability studies in cattle barns has been developed partly for this purpose and partly adopted from other fields of application e.g. as presented by Pesonen-Leinonen (2005), Kuisma (2006) and Määttä (2007). Visual assessment methods have mostly been used in field studies (Table 1), whereas microbiological and instrumental detection methods have been used in both laboratory and field studies (Tables 2 and 3). Radiochemistry (Table 3 ) is a chemical quantitative method that can be used only in the laboratory.

Laboratory and field studies give different and complementary information. In the study by Kuisma et al. (2008a), flooring materials for use in public offices were compared and ranked in similar order of superiority according to both laboratory and field experiments. Their study was based on colorimetric measurements. In the studies by Määttä et al. (2008 and 2009) and Kuisma et al. (2008b), focusing on surface materials for use in cattle barns, similar general observations were also made. In the study by Kuisma et al. (2008b), the materials were ranked in the same order of superiority according to colorimetric results in a cattle barn field study and radiochemical results from laboratory studies by Määttä et al. (2008 and 2009). However, laboratory experiments are important prior to field experiments to screen potential materials, whereas field studies provide practical information about the behaviour of the surface materials examined (Kuisma et al. 2008a). A wide set of new surface materials can relatively easily be examined in the laboratory, even if no previous knowledge of their characteristics is available, and the ones with no potential for field use e.g. because of poor wear resistance can be ranked out. De Muynck et al.
(2008) suggested after their laboratory study that practical durability of surface materials should in general be demonstrated in field tests. However, field studies are often more resource-demanding than laboratory studies and in the case of animal houses an appropriate barn or piggery must be available for long-term use. On the other hand the fact that the focus of field studies has often been on animal behaviour (Table 1) leads to the need for field studies rather than laboratory studies.

It is generally known that different kinds of detection methods often yield complementary information. According to this review different detection methods have been used for measurement of different hygiene levels and with different study designs. This valuable information can be utilized when selecting new materials and for managing animal welfare and food safety.

\section{Conclusions}

Animal welfare as well as food safety, material development and also work safety were mentioned as motivating factors for including cleanability measurements in the studies reviewed. The main single motivation factor for studies including hygiene assessment was animal welfare. Visual assessment methods dominated in field studies, but optical instrumental detection methods have also been used. Instrumental detection methods included e.g. colorimetry, other optical methods and radiochemistry. Radiochemical methods proved to be suitable as quantitative laboratory methods, although they require special skills and equipment. Microbiological methods were used in some laboratory and field studies. In laboratory studies both natural soils and different kinds of model soils were used. When evaluating surface materials, laboratory experiments are important prior to field experiments, whereas field studies provide practical information about the behaviour of the surface materials. 
Vol. 18 (2009): 268-282.

\section{References}

Aarnink, A.J.A. \& Wagemans, M.J.M. 1997. Ammonia volatilization and dust concentration as affected by ventilation systems in houses for fattening pigs. Transactions of the ASAE 40: 1161-1170.

Aarnink, A.J.A. \& Verstegen, M.W.A. 2007. Nutrition, key factor to reduce environmental load from pig production. Livestock Science 109: 194-203.

Abdelmseeh, V.A., Jofriet, J. \& Hayward, G. 2008. Sulphate and sulphide corrosion in livestock buildings, Part I: Concrete deterioration. Biosystems Engineering 99: 372-381.

ACI 515.1R-79. 1985. A guide to the use of waterproofing, dampproofing, protective, and decorative barrier systems for concrete. ACI Manual of concrete practice 1988, Part 5. American concrete institute, USA. 44 p.

Almuhanna, E.A. 2007. Dust control in livestock buildings with electrostatically-charged water spray. Academic dissertation, Kansas State University, USA. 212 p.

Almusallam, A.A., Khan, F.M., Dulaijan, S.U. \& Al-Amoudi, O.S.B. 2003. Effectiveness of surface coatings in improving concrete durability. Cement Concrete Compos 25: 473-481.

Andersen, H.J., Oksbjerg, N. \& Therkildsen, M. 2005. Potentilan quality control tools in the production of fresh pork, beef and lamb demanded by the European society. Livestock Production Science 94: 105-124.

Barbucci, A., Delucchi, M. \& Gerisola, G. 1997. Organic coatings for concrete protection: liquid water and water vapour permeabilities. Progress in Organic coatings 30: 293-297.

Barker, Z.E., Amory, J.R., Wright, J.L., Blowey, R.W. \& Green, L.E. 2007. Management factors associated with impaired locomotion in dairy cows in England and Wales. Journal of Dairy Science 90: 3270-3277.

Baxter, S. 1984. Intensive Pig Production. Environmental Management and Design. Granada Publishing, London. 588 p.

Berends, B.R., Urlings, H.A., Snijders, J.M., Van Knapen, F. 1996. Identification and quantification of risk factors in animal management and transport regarding Salmonella spp. in pigs. International Journal of food Microbiology 30: 37-53.

Bertron, A., Duchesne, J. \& Escadeillas, G. 2005. Attack of cement pastes exposed to organic acids in manure. Cement \& Concrete Composites 27: 898-909.

Botermans, J.A.M. \& Svendsen, J. 2000. Effect of feeding environment on performance, injuries and behaviour in growing-finishing pigs: group-based studies. Acta Agriculturae Scandinavica, Section A - Animal Sciences 50: 237-249.

Braam, C.R., Ketelaars, J.J.M.H. \& Smits, M.C.J. 1997a. Effects of floor design and floor cleaning on ammonia emission from cubicle houses for dairy cows. Netherlands Journal Agricultural Science 45: 49-64.

Braam, C.R., Smits, M.C.J., Gunnink, H. \& Swierstra, D. 1997b. Ammonia emission from a double-sloped solid floor in a cubicle house for dairy cows. Journal of Agricultural Engineering Research 68: 375-386.

Braithwaite, I., Blanke, M., Zhang, G-Q. \& Carstensen, J.
2005. Design of a visionbased sensor for autonomous pig house cleaning. Journal on Applied Signal Processing 13: 2005-2017.

Böhm, R. 1998. Disinfection and hygiene in the veterinary field and disinfection of animal houses and transport vehicles. International Biodeterioration \& Biodegradation 41: 217-224.

Calleja Carrete, J. 2005. The aggressive agents for concrete in agricultural, livestock and agroalimentary industries. In: Proceedings of the V International Symposium "Concrete for a sustainable agriculture", 5-8 June 2005. San Lorenzo de El Escorial, Spain. p. 139-152.

Cole, D., Todd, L. \& Wing, S. 2000. Concentrated swine feeding operations and public health: A review of occupational and community health effects. Environmental Health Perspectives 108: 685-699.

De Belie, N. 1997. A survey on concrete floors in pig houses and their degration. Journal of Agricultural Engineering research 66: 151-156.

De Belie, N., de Blaere, B. \& Verschoore, R. 1996. Compounds aggressive to concrete floors in pig houses. Landwards 51: 22-26.

De Belie, N., Lenehan, J.J., Braam, C.R., Svennerstedt, B., Richardson, M. \& Sonck, B. 2000a. Durability of building materials and components in the agricultural environment, Part III: Concrete structures. Journal of Agricultural Engineering Research 75: 3-16.

De Belie, N., Richardson, M., Braam, C.R., Svennerstedt, B., Lenehan, J.J. \& Sonck, B. 2000b. Durability of building materials and components in the agricultural environment, Part I: The agricultural environment and timber structures. Journal of Agricultural Engineering Research 75: 225-241.

De Belie, N. \& Rombaut, E. 2003. Characterization of claw-floor contact pressures for standing cattle and the dependency on concrete roughness. Biosystems Engineering 85: 339-346.

De Belie, N., Sonck, B., Braam, C.R., Lenehan, J.J., Svennerstedt, B. \& Richardson, M. 2000c. Durability of building materials and components in the agricultural environment, Part II: Metal structures. Journal of Agricultural Engineering Research 75: 333-347.

De Koning, K., Slaghuis, B. \& van der Vorst, Y. 2003. Robotic milking and milk quality: effects on bacterial counts, somatic cell counts, freezing points and free fatty acids. Italian Journal of Animal Science 2: 291-299.

De Muynck, W., Debrouwer, D., de Belie, N. \& Verstraete, W. 2008. Bacterial carbonate precipitation improves the durability of cementitious materials. Cement and concrete Research 38: 1005-1014.

De Palo, P., Tateo, A., Zezza, F., Corrente, M. \& Centoducati, P. 2006. Influence of free-stall flooring on comfort and hygiene of dairy cows during warm climatic conditions. Journal of Dairy Science 89: 4583-4595.

Engström, S. \& Bäckström, K. 1987. Ellipsometry as a tool to study detergency at hard surfaces. Langmuir 3: 568-574.

Farzan, A., Friendship, R.M., Dewey, C.E., Warriner, K., Poppe, C. \& Klotins, K. 2006. Prevalence of Salmonella spp. on Canadian pig farms using liquid or dry-feeding. Preventive Veterinary Medicine 73: 241-254.

Galton, D.N.R., Adkinson, R.W., Thomas, C.V. \& Smith, T.W. 1982. Effects of premilking udder preparation on 
Kymäläinen, H.-R. et al. Assessment of cleanness of surfaces in animal houses

environmental bacterial contamination of milk. Journal of Dairy Science 65: 1540-1543.

Gaworski, M.A., Tucker, C.B., Weary, D.M. \& Swift, M.L. 2003. Effects of stall design on dairy cattle behaviour in Proceedings Dairy Housing Conference, Fort Worth, TX. American Society of Agricultural Engineers, St Joseph, MI. pp. 139-146.

Gjødesen, M. U. 2007. Automatiske foderanlæg. FarmTest Kvæg nr. 39/2007. 43 p.

Hanus, O., Frelich, J., Vyletelova, M., Roubal, P., Vorlicek, Z. \& Jedelska, R. 2004. Technologically difficult, pathogenic and food risky bacterial contamination of raw milk and other materials from dairy cow herds. Czech Journal of Animal Science 49: 489-499.

Harry, E.G. 1978. Air pollution in farm buildings and methods of control: a review. Avian Pathology 7: 441-454.

Hautekiet, V., Geert, V., Marc, V. \& Rony, G. 2008. Development of a sanitary index for Salmonella seroprevalence in Belgian pig farms. Preventive Veterinary Medicine 86: 75-92.

Hovinen, M., Aisla, A.-M. \& Pyörälä, S. 2005. Visual detection of technical success and effectiveness of teat cleaning in two automatic milking systems. Journal of Dairy Science 88: 3354-3362.

Hoy, S., Ziron, M. \& Iben, B. 1999. Entstehung und Auswirkungen von sekundären Effloreszenzen bei Ferkeln sowie Möglichkeiten ihrer Verhinderung. Der Praktische Tierartz 80: 698-706.

Hultgren, J. \& Bergsten, C. 2001. Effects of a rubber-slatted flooring system on cleanliness and foot health in tied dairy cows. Preventive Veterinary Medicine 52: 75-89.

Hörndahl, T. 1995. Slitstyrka och halksäkerhet hos golv $i$ djurstallar, Inverkan av material och utförande. (Wearing quality and prevention of slipperiness on solid floors in animal houses. Influence of materials and performance). Specialmeddelande 220, Sveriges Lantbruksuniversitet, Institutionen för Jordbrukets Biosystem och Teknologi, Lund, Sweden. 49 p. (in Swedish)

Ipema, A.H. 1997. Integration of robotic milking in dairy housing systems. Review of cow traffic and milking capacity aspects. Computers and Electronics in Agriculture 17: 79-94.

Jayarao, B.M., Pillai, S.R., Sawant, A.A., Wolfgang, D.R. \& Hedge, N.V. 2004. Guidelines for monitoring bulk tank milk somatic cell and bacterial counts. Journal of Dairy Science 87: 3561-3573.

Jokelainen, A. \& Uusi-Rauva, A. 1976. Reinigung von Linoleum- und PVC-Bodenbelägen von radioaktivem Partikelschmutz. Seifen-Öle-Fette-Wachse 72: 443-445.

Knappstein, K., Roth, N., Slaghuis, B., Ferwerda-van Zonneveld, R., Walte, H.-G. \& Reichmuth, J. 2004. Farm hygiene and teat cleaning requirements in automatic milking. In: Automatic Milking - a better understanding, Wageningen, March 2004. - Wageningen: Wageningen Academic Publishers, p. 83-93.

Kremer, P.V., Nueske, S., Scholz, A.M. \& Foerster, M. 2007. Comparison of claw health and milk yield in dairy cows on elastic or concrete flooring. Journal of Dairy Science 90: 4603-4611.

Kuisma, R. 2006. Physical characterization of plastic surfaces in wearing and cleanability research. Academic dissertation. University of Helsinki, Department of Agro- technology, MMTEK publications 22. $77 \mathrm{p}$.

Kuisma, R., Kymäläinen, H.-R. \& Sjöberg, A.-M. 2008a. Determination of cleanability and wearing of plastic flooring surfaces in field and laboratory conditions. Construction and Building Materials 23: 1093-1101.

Kuisma, R., Kymäläinen, H.-R., Hellstedt, M., Jauhiainen, P., Määttä, J. \& Sjöberg, A.-M. 2008b. Properties and cleanability of new and traditional surface materials in cattle barns - a field study. Agricultural and Food Science 17: 227-229.

Kymäläinen, H.-R., Määttä, J., Joutsen, B.-L., Puumala, M., Kaustell, K. \& Sjöberg, A.-M. 2008. Effect of coating on cleanability of concrete as flooring material in piggeries. Biosystems Engineering 99: 88-98.

Larsson, K. 2000. Rengöring av svinstall. (Cleaning of pighouses) JTI-rapport Lantbruk \& Industri Nr 266, Jordbrukstekniska institutet, Uppsala, Sweden. 49 p.

Lorentzon, S. 2005. Hygiene studies in cubicle cowsheds with different floor systems in the passages. Swedish University of Agricultural Sciences, Dept of Agricultural Biosystems and Technology. Examensarbete 15, Thesis, Alnarp. $26 \mathrm{p}$.

Määttä, J. 2007. Modifications of surface materials and their effects on cleanability as studied by radiochemical methods. MMTEK-Publications 26. Department of Agrotechnology, University of Helsinki, Finland. Yliopistopaino. $61 \mathrm{p}$.

Määttä, J., Hellstedt, M., Kuisma, R., Kymäläinen, H.-R., Mahlberg, R. \& Sjöberg, A.-M. 2009. Effects of chemical and mechanical wearing on cleanability and surface properties of traditional and new surface materials in cattle barns - a laboratory study. Biosystems Engineering 103: 464-473.

Määttä, J. Koponen, H.-K., Kuisma, R., Kymäläinen, H.-R., Pesonen-Leinonen, E., Uusi-Rauva, A., Hurme, K.-R., Sjöberg, A.-M., Suvanto, M. \& Pakkanen, T.A. 2007. Effect of plasticizer and surface topography on the cleanability of plasticized PVC materials. Applied Surface Science 253: 5003-5010.

Määttä, J., Kymäläinen, H.-R., Puumala, M., Mahlberg, R., Kuisma, R., Salparanta, L., Löija, M., Talibachew, A., Hurme, K.-R., Uusi-Rauva, A., Ritschkoff, A.-R. \& Sjöberg, A.-M. 2008. Properties and cleanability of new and traditional surface materials. Agricultural and Food Science 17: 210-226.

Madec, F., Bridoux, N., Bounaix, S. \& Jestin, A. 1998. Measurement of digestive disorders in the piglet at weaning and related risk factors. Preventive Veterinary Medicine 35: 53-72.

Mahlberg, R., Hellstedt, M., Jauhiainen, P., Kuisma, R., Kymäläinen, H.-R., Määttä, J., Salparanta, L., Sjöberg, A.-M. \& Ritchskoff, A.-C. 2008. Helposti puhdistettavat lattiamateriaalit lypsykarjatiloissa. VTT Tiedotteita 2447, Edita Prima Oy, Helsinki. 66 p. (in Finnish)

Mathiasson, L., Knutsson, M., Bremle, G. \& Mårtensson, L. 1991. Chemical environment in animal buildings. Swedish Journal of Agricultural Research 21: 147-155.

Maw, S.J., Fowler, V.R., Hamilton, M. \& Petchey, A.M. 2001. Effect of husbandry and housing of pigs on the organoleptic properties of bacon. Livestock Production Science 68: 119-130

Miller, D.N. \& Woodbury, B.L. 2003. Simple protocols to determine dust potentials from cattle feedlot soil and 
Vol. 18 (2009): 268-282.

surface samples. Journal of Environmental Quality 32: 1634-1640.

Moon, H.Y., Shin, D.G. \& Choi, D.S. 2007. Evaluation of the durability of mortar and concrete applied with inorganic coating material and surface treatments system. Construction \& Building Materials 21: 362-369.

Mottram, T. 1997. Requirements for teat inspection and cleaning in automatic milking systems. Computers and Electronics in Agriculture 17: 63-77.

Naik, T.R., Singh, S.S. \& Ramme, B.W. 2002. Effect of source of fly ash abrasion resistance of concrete. Journal of Materials in Civil Engineering 14: 417-426.

Ndegwa, P.M., Hristov, A.N., Arogo, J. \& Sheffield, R.E. 2008. A review of ammonia emission mitigation techniques for concentrated animal feeding operations. Biosystems Engineering 100: 453-469.

Ni, J.Q., Vinckier, C., Coenegrachts, J. \& Hendriks, J. 1999. Effect of manure on ammonia emission from a fattening pig house with partly slatted floor. Livestock Production Science 59: 25-31.

Nilsson, C. 2005. Use of concrete for floors in livestock buildings. In: Concete for a suitable agriculture, Agroaqua and community applications. Proceedings of the Vth International Symposium on 5-8 June 2005. San Lorenzo de El Escorial, Spain. p. 25-32.

Ohlson, H. \& Wäänänen, M. 1971. Determination of soiling of flooring materials by using artificial radioactive soils. The State Institute for Technical Research, Tiedotus. Sarja III-Rakennus 160. Helsinki. VTT Offsetpaino. p.38.

Pedersen, S., Nonnenmann, M., Rautiainen, R., Demmers, T.G.M., Banhazi, T. \& Lyngbye, M. 2000. Dust in pig buildings. Journal of agricultural safety and health 6: 261-274.

Pell, A.N. 1997. Manure and microbes: public and animal health problem ? Journal of Dairy Science 80: 26732681.

Pelletier, F., deFoy, C., Marquis, A., Godbout, S., Joncas, R., Gagné, R. \& Massé, D. 2002. Effects of different concrete types on gas, odour emissions and sanitation of swine buildings. In: Concete for a suitable agriculture, Agro- aqua and community applications. Proceedings of the IVth International Symposium 21-24 April 2002. Ghent, Belgium. p. 287-294.

Pesonen-Leinonen, E. 2005. Determination of cleanability of plastic surfaces. MMTE Publications 21. Department of Agrotechnology, University of Helsinki, Finland. Yliopistopaino. p.64.

Pesonen-Leinonen, E., Redsven, I., Neuvonen, P., Hurme, K.R., Pääkkö, M., Koponen, H.-K., Pakkanen, T.T., UusiRauva, A., Hautala, M. \& Sjöberg, A.-M. 2006. Determination of soil adhesion to plastic surfaces using a radioactive tracer. Applied Radiation Isotopes 64: 163-169.

Phillips, P.A. \& Phillips, M.H. 1999. Effect of dispenser on water intake of pigs at weaning. Transactions of the ASAE 42: 1471-1473.

Preller, L., Heedrick, D., Kromhout, H., Boleij, J.S.M. \& Tielen, M.J.M. 1995. Determinants of dust and endotoxin exposure of pig farmers: development of a control strategy using empirical modelling. Annals of occupational hygiene 39:545-557.

Puumala, M., Jauhiainen, P., Mattila, T., Kaustell, K.O., Komonen, J., Kymäläinen, H.-R., Joutsen, B.-L., Sjöberg,
A.-M., Norring M., Valros, A. \& Saloniemi, H. 2006. Kotieläinrakennusten lattioiden pinnan laatu. MTT:n selvityksiä 110, Vihti. 78 p. (in Finnish)

Puumala, M. \& Lehtiniemi, T. 1993. Betonit ja muovit navetan lattiamateriaaleina. (Concrete and plastic as floor materials in barns) Vakolan tutkimusselostus 67, MTT, Vihti, Finland. 85 p. (in Finnish)

Rasmussen, M.D., Bjerring, M., Justesen, P. \& Jepsen, L. 2002. Milk quality on Danish farms with automatic milking systems. Journal of Dairy Science 85: 2869-2878.

Rushen, J. \& Passillé, A.M. de. 2006. Effect of roughness and compressibility of flooring on cow locomotion. Journal of Dairy Science 89: 2965-2972.

Ruunaniemi, J., Hautala, M. \& Ahokas, J. 2005. Physical properties of synthetic bedding materials for free-stall dairy cow. Agricultural and Food Science 14: 134-142.

Sánchez, E., Massana, J., Garcimartín, M.A. \& Moragues, A. 2008. Mechanical strength and microstructure evolution of fly ash cement mortar submerged in pig slurry. Cement and Concrete Research 38: 717-724.

Scott, K., Chennells, D.J., Armstrong, D., Taylor, L., Gill, B.P. \& Edwards, S.A. 2007. The welfare of finishing pigs under different housing and feeding systems: liquid versus dry feeding in fully-slatted and straw-based housing. Animal Welfare 16: 53-62.

Siekkinen, K.-M., Nuotio, L., Ranta, J., Laukkanen, R., Hellström, S., Korkeala, H. \& Maijala, R. 2006. Assessing hygiene proficiency on organic and conventional pig farms regarding pork safety: A pilot study in Finland. Livestock Science 104: 193-202.

Skrzypek, R. 2006. Factors affecting somatic cell count and total microorganisms count in cow's milk. Polish Journal of Food and Nutrition Sciences 15/56: 209-213.

Slaghuis, B. 1996. Sources and significance of contaminants on different levels of raw milk production. In Proceedings of IDF Symposium Bacteriological quality of raw milk. Wolfpassing, Autria. IDF, Brussels, Belgium. pp. 19-27.

Stefanowska, J., Swierstra, D., Braam, C.R. \& Hendriks, M.M.W.B. 2001. Cow behaviour on a new grooved floor in comparison with a slatted floor, taking claw health and floor properties into account. Applied Animal Behaviour Science 71: 87-103.

Sumner, J. 1996. Farm production influences on milk hygiene quality. In Proceedings of IDF Symposium Bacteriological quality of raw milk. Wolfpassing, Autria. IDF, Brussels, Belgium. pp. 94-102.

Sun, H., Trabue, S.L., Scoggin, K., Jackson, W.A., Pan, Y., Zhao, Y., Malkina, I.L., Koziel, J.A. \& Mitloehner, F.M. 2008. Alcohol, volatile fatty acid, phenol, and methane emissions from dairy cows and fresh manure. Journal of Environmental Quality 37: 615-622.

Sundahl, A.-M. 1974. Byggnadsmaterial i djurstallar, Nedsmutsing - rengöring. (Building materials in animal houses, Soiling-cleaning). Sveriges Lantbruksuniversitet, Inst. för landbrukets byggnadsteknik, Aktuellt 211, Teknik, Uppsala, Sweden. 33 p. (in Swedish)

Svensson, C., Hultgren, J. \& Oltenacu, P.A. 2006. Morbidity in 3-7 -month old dairy calves in south-western Sweden, and risk factors for diarrhoea and respiratory disease. Preventive Veterinary Medicine 74: 162-179.

Swierstra, D., Smits, M.C.J. \& Kroodsma, W. 1995. Ammonia emission from cubicle houses for cattle with slat- 
Kymäläinen, H.-R. et al. Assessment of cleanness of surfaces in animal houses

ted and solid floors. Journal of agricultural Engineering Research 62: 127-132.

Telezhenko, E. 2007. Effect of flooring system on locomotion comfort in dairy cows: aspects of gait, preference and claw condition. Doctoral thesis, Swedish University of Agricultural Sciences, Faculty of Veterinary Medicine and Animal Science, Dept of Animal Environment and Health, Skara. Acta Universitatis Agriculturae Sueciae 2007:76. 55 p.

Trevisi, E., Bionaz, M., Piccioli-Cappelli, F. \& Bertoni, G. 2006. The management of intensive dairy farms can be improvd for better welfare and milk yield. Livestock Science 103: 231-236.

Tuyttens, F.A.M. 2005. The importance of straw for pig and cattle welfare: A review. Applied Animal Behaviour Science 92: 261-282.

Vokey, F.J., Guard, C.L., Erb, H.N. \& Galton, D.M. 2001. Effects of alley and stall surfaces on indices of claw and leg health in dairy cattle housed in a free-stall barn. Journal of Dairy Science 84: 2686-2699.

von Borell, E., Bockisch, F.-J., Buscher, W., Hoy, S., Krieter, J., Muller, C., Parvizi, N., Richter, T., Rudovsky, A., Sundrum, A. \& Van den Weghe, H. 2001. Critical control points for on-farm assessment of pig housing. Livestock Production Science 72: 177-184.

Wathes, C.M,m Phillips, V.R., Holden, M.R., Sneath, R.W., Short, J.L., White, R.P., Hartung, J., Seedorf, J., Schröder, M., Linkert, K.H., Pedersen, S., Takai, H.,
Johnsen, J.O., Groot Koerkamp, P.W.G., Uenk, G.H., Metz, J.H.M., Hinz, T., Caspary, V. \& Linke, S. 1998. Emissions of aerial pollutants in livestock buldings in Northern Europe: overview of a multinational project. Journal of Agricultural Engineering Research 70: 3-9.

Wells, S.J., Garber, L.P. \& Wagner, B.A. 1999. Papillomatous digital dermatitis and associated risk factors in US dairy herds. Preventive Veterinary Medicine 38: 11-24.

Wong Lo Fo, D.M.A., Hald, T., van der Wolf, P.J. \& Swanenburg, M. 2002. Epidemiology and control measures for Salmonella in pigs and pork. Livestock Production Science 76: 215-222.

Xiao, L., Herd, R.P. \& Bowman, G.L. 1994. Prevalence of Cryptosporium and Giardia infections on two Ohio pig farms with different management systems. Veterinary Parasitology 52: 331-336.

Yazıcı, Ş. \& İnan, G. 2006. An investigation on the wear resistance of high strength concretes. Wear 260: 615618.

Ye, Z., Li, B., Cheng, B., Chen, G., Zhang, G., Shi, Z., Wei, X. \& Xi, L. 2007. A concrete slatted floor system for separation of faeces and urine in pig houses. Biosystems Engineering 98: 206-214.

Zhang, G., Strøm, J.S., Blanke, M. \& Braithwaite, I. 2006. Spectral signatures of surface materials in pig buildings. Biosystems Engineering 94: 495-504.

\title{
SELOSTUS
}

\section{Pintojen puhtauden mittaaminen navetoissa ja sikaloissa}

\author{
Hanna-Riitta Kymäläinen, Risto Kuisma, Jenni Määttä, Anna-Maija Sjöberg \\ Helsingin yliopisto, Agroteknologian laitos
}

Karjasuojien pintojen puhtaus on merkittävä elintarvikkeiden laatuun, tuotantoeläinten hyvinvointiin ja jopa työntekijöiden hyvinvointiin vaikuttava tekijä. Tämän tutkimuksen tarkoituksena oli tarkastella kirjallisuuskatsauksena navetoiden ja sikaloiden puhtaustutkimuksessa käytettyjä menetelmiä. Tutkimuksessa käsiteltiin myös pintamateriaaleja, tuotantoeläinten hyvinvointia ja hygieniaa. Katsauksen mukaan kenttätutkimuksissa käytettiin yleensä visuaalisia puhtauden arviointimenetelmiä, mutta myös joitakin lupaaviksi osoittautuneita optisten menetelmien sovelluksia esiteltiin kenttätutkimuksissa. Sen sijaan laboratoriotutkimuksiin sisältyi laajempi valikoima instrumentaalisia, mikrobiologisia ja visuaalisia menetelmiä sekä niiden yhdistelmiä. Ainoita käytettyjä kvantitatiivisia laboratoriomenetelmiä olivat radiokemialliset menetelmät. Katsauksen mukaan kenttäkokeita edeltäviä laboratoriokokeita pidettiin tarpeellisina vertailevissa materiaalitutkimuksissa, mutta kuitenkin vasta kenttäkokeiden perusteella materiaalien todellinen käyttäytyminen käytännössä saatiin selville. Katsauksessa sikaloiden ja navetoiden pintojen puhtauden merkitystä tarkasteltiin myös materiaalikehityksen näkökulmasta. 